\title{
Somaclonal variations for crop improvement: Selection for disease resistant variants in vitro
}

\author{
Veena S Anil*, Spurti Bennur and Savitha Lobo \\ Department of Plant Biotechnology, Gandhi Krishi Vignana Kendra (GKVK), University of Agricultural Sciences (UAS), Bangalore \\ 560065, India
}

Article history

Received: 07 February 2018

Accepted: 04 March 2018

Published: 01 April 2018

(C) Anil et al (2018)

Editor

K K Sabu

Publisher

Horizon e-Publishing Group

Correspondence

Veena S Anil

凶veenaanil@ymail.com

\begin{abstract}
Somaclonal variations (SV) are genetic or epigenetic changes induced in plant cell and tissue culture. Induction of somaclonal variation, is an alternate approach to conventional breeding and transgenic approaches to introduce desirable genetic variability in the gene pool. SVs that occur spontaneously in culture induce changes in a range of plant characters. However, the probability of improving a key agronomic trait such as disease resistance can be cumbersome when left to chance alone. The efficiency of developing disease resistant SVs is better with the imposition of an appropriate in vitro selection pressure. Selection agents that have been applied include pathogen elicitors, pathogen culture filtrate and purified pathotoxins. This method of SV selection has been successful in enhancing disease resistance in several crops and it is an accepted biotechnological approach with tremendous potential for crop improvement.
\end{abstract}

\section{Keywords}

Somaclonal variations (SV); biotechnology; crop improvement; in vitro selection, disease resistance; culture filtrate; pathotoxins

\section{Citation}

Anil V S, Bennur S, Lobo S. Somaclonal variations for crop improvement: Selection for disease resistant variants in vitro. Plant Science Today 2018;5(2):44-54. https://dx.doi.org/10.14719/pst.2018.5.2.382

\section{Introduction}

Biotic stresses are major constraints that contribute to yield losses, and to the failure of crops realizing their full yield potential. Breeding is the conventional approach to introduce genetic changes for crop trait improvement including disease resistance. Resistance may arise from the introduction of resistance (R) genes, which remains effective over a period of time until overcome by an ever evolving pathogen, thus limiting the shelf life of the effectiveness of the cultivars. In addition, breeding approaches can fail due to lack of genetic variability in a crop species or its wild relatives. In this scenario, biotechnological approaches such as the development of transgenic plants and the in vitro selection of somaclonal variations, become viable alternatives to support the breeding programmes for crop improvement. Among these alternatives, transgenic approach is yet to gain public acceptance, and has to adhere to stringent biosafety regulations of the country in which the transgenic crop is developed, tested and cultivated. The somaclonal variant approach is based on changes resulting from internal mutations and thus does not face acceptability issues nor pose any known biosafety concerns. SVs can be considered an alternate source of exploitable variation induced in cell and tissue culture. This mini review briefly 
highlights the resistance mechanisms existing in plants and details the approaches used in enhancing disease resistant traits in crop plants. The review focuses on somaclonal variations as a potential technology in crop trait improvement in general and more specifically for developing disease resistant variants.

\section{Disease Resistance}

Plants, are constantly exposed to various pathogens and pests but very few are successful in establishing an infection and causing disease. Occurrence of disease in nature is rare as plants have evolved multiple, sophisticated and overlapping mechanisms of defense including defensive structures, toxins, antimicrobials, barriers such as callose, suberins, waxes, and more specific adaptive defense such as non-host defense, vertical-race-specific and horizontal multigenic resistance.

\section{Types of disease resistance}

i) Vertical resistance: The term was first coined by Vanderplank during 1963 (1) to describe singlegene resistance. In vertical resistance, plant possesses single genes for resistance [example, Resistance (R) genes], while the pathogen possesses single genes for pathogenicity [example Avirulence (Avr) genes], which interact and recognize each other at the protein level. This is known as the gene-for-gene relationship between a pathogen and host, and is the basis of vertical resistance. It is qualitative resistance or race specific resistance regulated by major genes which is effective but can be easily overcome by new races of the pathogen. In other words, the pathogen can mutate its Avr genes to escape recognition by the host $\mathrm{R}$ gene, thus by-passing an effective resistance response in the host.

ii) Horizontal resistance: This term was also coined by Vanderplank (1) and represents a quantitative or durable resistance, controlled by several genes. It is also sometimes referred to as generalized resistance. Horizontal resistance and horizontal pathogenicity are entirely independent of each other in genetic terms, that is, there is no gene-for-gene relationship in this phenomenon. The polygenic resistance genes of horizontal resistance provide the plants with defensive structures or toxins that slow down or stop the pathogenic infection. The resistance may not be as precise as the race specific vertical resistance and develops at a slower rate. However it is a durable resistance and does not break down to new races of the pathogen, as does vertical resistance.

\section{Need for Disease Resistant Crops}

Agriculture involves large areas of monoculture of genetically identical crops, which is very unlike the coexistence of different plant species in a natural ecosystem. During domestication, crops have gained in yield potential, but have lost out on resistance traits of their wild ancestors. Crop disease contributes to an average loss of $26 \%$ of the global crop production annually (2). Crop cultivation relies on a few in-bred disease resistance genes and on excessive application of pesticides to manage pathogens. Despite their effectiveness pesticides have deleterious environmental consequences and the development of genetically resistant cultivars becomes a paramount goal. It is indeed a major challenge to attain food security, in the backdrop of population explosion, climate change, soil salinity, drought and soil erosion. Developing long-lasting and broad-spectrum disease resistance in crops will contribute in the quest to attain yield stability and food security.

\section{Approaches to enhance disease resistance}

i) Breeding approach: Plant breeders focus a significant part of their effort on selection and development of disease resistant plant lines. Crop varieties and wild ancestral species with inherent disease resistance genes are generally the source of resistance in breeding programmes. A diseasesusceptible desirable crop cultivar is crossed with a variety with suitable resistance trait to obtain populations that segregate for the traits of the parents. Crossing includes cumbersome phenotypic selection, and methods such as marker assisted selection, backcross breeding, pedigree and bulk methods.

Breeding for disease resistance has been an ongoing process since the domestication of plants but it requires persistence, takes many years to develop and the resulting cultivar may revert to susceptibility in a few years. This is because pathogens are under natural selection for enhancing their pathogenicity. Thus with time and the right mutations pathogens can overcome the plant's resistance. Moreover new pathogens maybe introduced to the area, changes in cultivation practice can trigger incidence of new diseases, and sometime breeding for other characters can disrupt the disease resistance present in the parent varieties. Many a times the crop species may have limited genetic variability making breeding programs unviable. In some instances related wild species may possess the required resistance genes, however crossability barriers prevent the use of such putative wild parents. To overcome some of these short comings and to hasten the process of developing new cultivars, conventional breeding is now integrated to other modern methods such as genetic engineering, somatic hybridization, double haploid and multiparent advanced generation inter-cross (MAGIC) populations (3). 
Table 1. Examples of in vitro selection for disease resistance in crop plants

\begin{tabular}{|c|c|c|c|c|}
\hline No & Crop & Selective agent & Resistance & References \\
\hline 1 & Carica papaya & $\begin{array}{l}\text { Sporangial } \\
\text { suspension }\end{array}$ & Phytophthora palmivora & $(46)$ \\
\hline 2 & Glycine max & Culture filtrate & Septoria glycines & $(47)$ \\
\hline 3 & Gossypium hirsutum & Culture filtrate & Fusarium oxysporum, Alterania macrospora & $(48)$ \\
\hline 4 & Hordium vulgare & Fusaric acid & Helminthosporium sativum & (49) \\
\hline 5 & $\begin{array}{l}\text { Lycopersicon } \\
\text { esculentum }\end{array}$ & Culture filtrate & Pyrenochaeta lycopersici & $(50)$ \\
\hline 6 & Medicago sativa & Culture filtrate & Fusarium oxysporum f. sp. medicaginis & $(51,52)$ \\
\hline 7 & Oryza sativa & Culture filtrate & Helminthosporium oryzae & (53) \\
\hline 8 & Psidium guajava & Cell free fitrate & Pencillium vermosonii & (54) \\
\hline 9 & Psidium guajava & Culture filtrate & Fusarium oxysporum & (55) \\
\hline 10 & Triticum aestivum & Deoxy-nivaenol & Fusarium graminearum & (56) \\
\hline 11 & Tobacco & $\begin{array}{l}\text { Methionine } \\
\text { suifoximine }\end{array}$ & Psuedomonas syringae & $(21)$ \\
\hline 12 & Saccharum officinarum & Phytotoxin & Colletotrichum falcatum & (57) \\
\hline 13 & Potato & $\begin{array}{l}\text { Fungi filtrate } \\
\text { culture }\end{array}$ & Phytophthora & (58) \\
\hline 14 & Ground nut & $\begin{array}{l}\text { Phytotoxin } \\
\text { selection }\end{array}$ & Carcosporidium peronatum & (35) \\
\hline 15 & Pigeon Pea & Culture filtrate & Fusarium odum & $(36)$ \\
\hline 16 & Potato & Culture Filtrate & Phytophthora infestans & $(22)$ \\
\hline 17 & Mango & Culture Filtrate & $\begin{array}{l}\text { Colletotrichum } \\
\text { gloeosporioides }\end{array}$ & (59) \\
\hline 18 & Sunflower & Culture filtrate & Alterneria helianthi & (39) \\
\hline 19 & Lemon & Pathogen Toxin & Phoma tracheiphila & $(60)$ \\
\hline 20 & Garlic & Culture filtrate & Sclerotium cepivorum & (61) \\
\hline 21 & Ginger & $\begin{array}{l}\text { Spore suspension } \\
\text { of pathogen }\end{array}$ & Fusarium oxysporum & $(40)$ \\
\hline
\end{tabular}

ii) Transgenic approach: Transgenic plants possess genetically engineered recombinant DNA and are considered as genetically modified organisms (GMO). This approach allows the introduction of a new trait that does not occur naturally in the species due to the artificial insertion of a gene or genes to the genome. The transgene may originate from a related plant or from a completely different species (from within and across Kingdoms) or may even be a completely synthetic gene. Cisgenic plants, on the other hand, have inserted gene(s) from the same species, however as the inserted gene is a recombinant DNA they are also considered as GMOs. Inserting a combination of genes (gene stacking) in a plant is more beneficial and productive as the introduced trait may last longer. Most genetically modified plants are generated by using the Agrobacterium tumefaciens mediated transformation method or by the biolistic method (Particle gun method) (4-5) which have both proved effective.

Over the last two decades genetic engineering and transgenic technology have been 


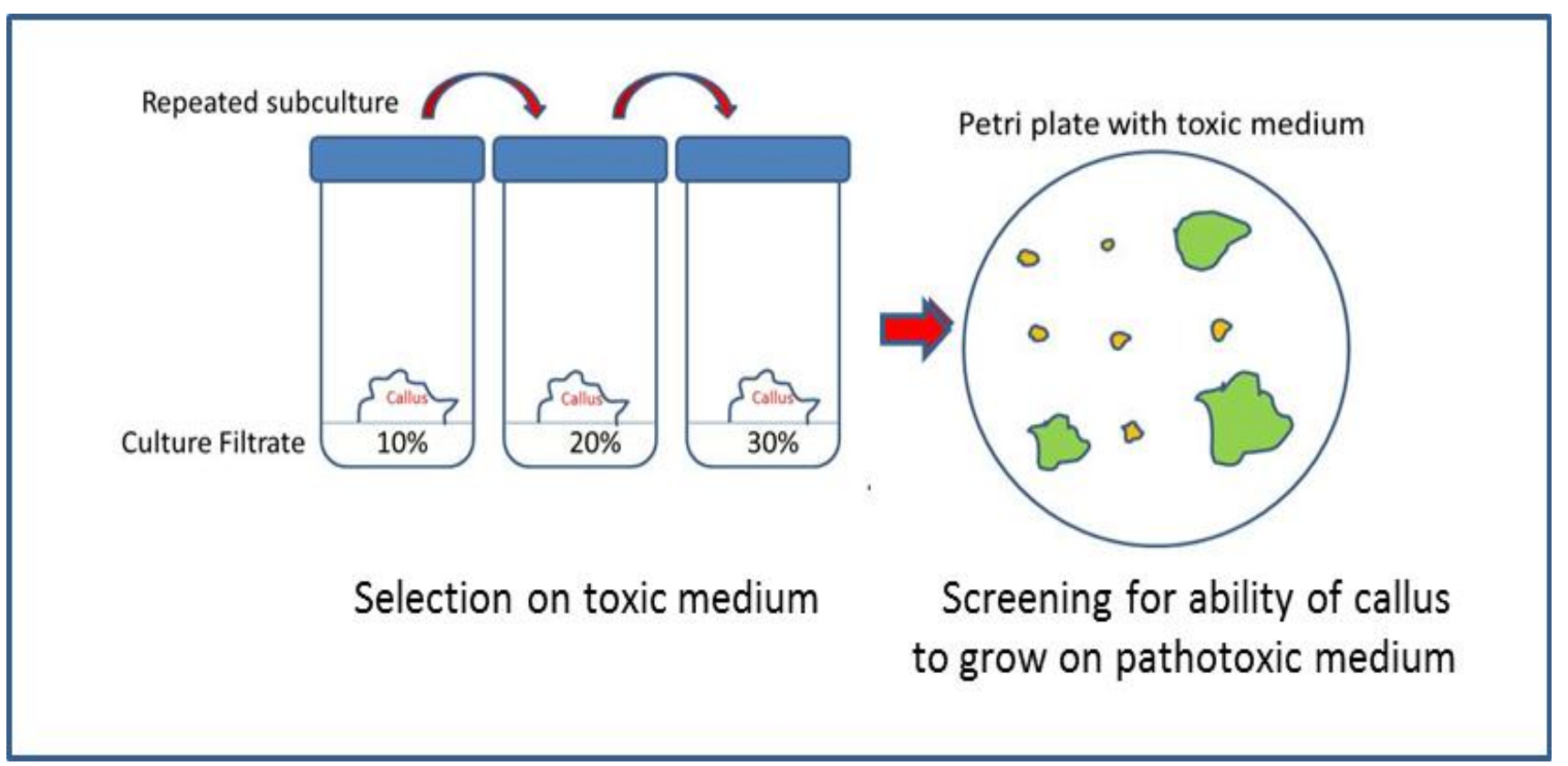

Fig 1. Schematic representation for a general methodology to select resistant Somaclonal variants

used in tandem to develop disease resistant crops. Genetic engineering has the potential to solve some of the problems of conventional breeding by inserting multiple genes that can confer long lasting broad-spectrum resistance. Recent advances in molecular techniques have unravelled some of the intricacies of the multifaceted nature of plant resistance mechanisms, which has in turn led to more sophisticated transgenic approaches to enhance resistance. A broader and in depth understanding of plant resistance along with transcriptomics, proteomics, metabolomic and protein interaction studies have thrown up several candidate genes from plants, bacteria, viruses and fungi that potentially can enhance resistance. These candidate genes can be constitutively over expressed, induced to express under biotic threat, tissue-specifically expressed, knocked out or silenced by RNAi to obtain the desired resistance trait. The technology has been successful in several crops and has potential to reduce losses incurred by biotic stress.

There have been instances of transgenics failing to perform, often due to the way in which the gene is expressed. Constitutively over expressed transgenes adversely affect plant size or seed production. Failure could also result due to disruption of an important endogenous gene by insertion of the transgene. In addition, there are concerns that 1) transgenic crops may cause allergies in people, 2) the marker antibiotic resistance genes, integrated in these crops can induce resistance to antibiotics, leading to super bugs, 3) transgenic crops can cause damage to the environment, by affecting beneficial microbiota and insects, and 4) there is the fear that genetic modifications maybe unintentionally transferred to other related species via the pollen. These concerns have led to the establishment of strict guidelines and regulation for the development and release of transgenic crops. These regulations are essential; nevertheless they slow down the development of transgenic crops. Transgenic plants have not been accepted in several societies many a times due to unsubstantiated notions or sentiments, such as reluctance to ingest DNA from virus, bacteria or animal sources. Thus the technology has not made inroads to the larger crop cultivation of several countries. However, transgenic food crops have been used for decades in the Americas without any proven ill-effects, and the advantages of the technology are many. It has great potential for developing superior traits for yield, abiotic and biotic stress tolerance, and can contribute to the much needed world's food stability.

iii) Somaclonal Variant Approach: Tissue culture derived plants are referred to as somaclones and tissue culture derived plants exhibiting divergences are referred to as somaclonal variants (6). Callus cultures can be used to recover somatic mutants because the in vitro culture milieu encourages the division of individual cell and regeneration of whole plant. Somaclonal variants can be somatically or genetically stable. The genetically stable variations can be termed mutations. However, because of the possibility of reversible epigenetic variations this area broadly uses the term 'variations' instead of 'mutations' (7).

Any change in the DNA sequence are heritable and important for crop improvement. On the other hand, epigenetic changes are temporary and reversible and not heritable (8). Genetically stable SVs can result due to point mutations, alterations in chromosome number and structure, recombinations, methylation of DNA sequences, deletions and transpositions in nuclear, mitochondrial or chloroplast genomes $(9,10)$. These genomic changes may result in stable 


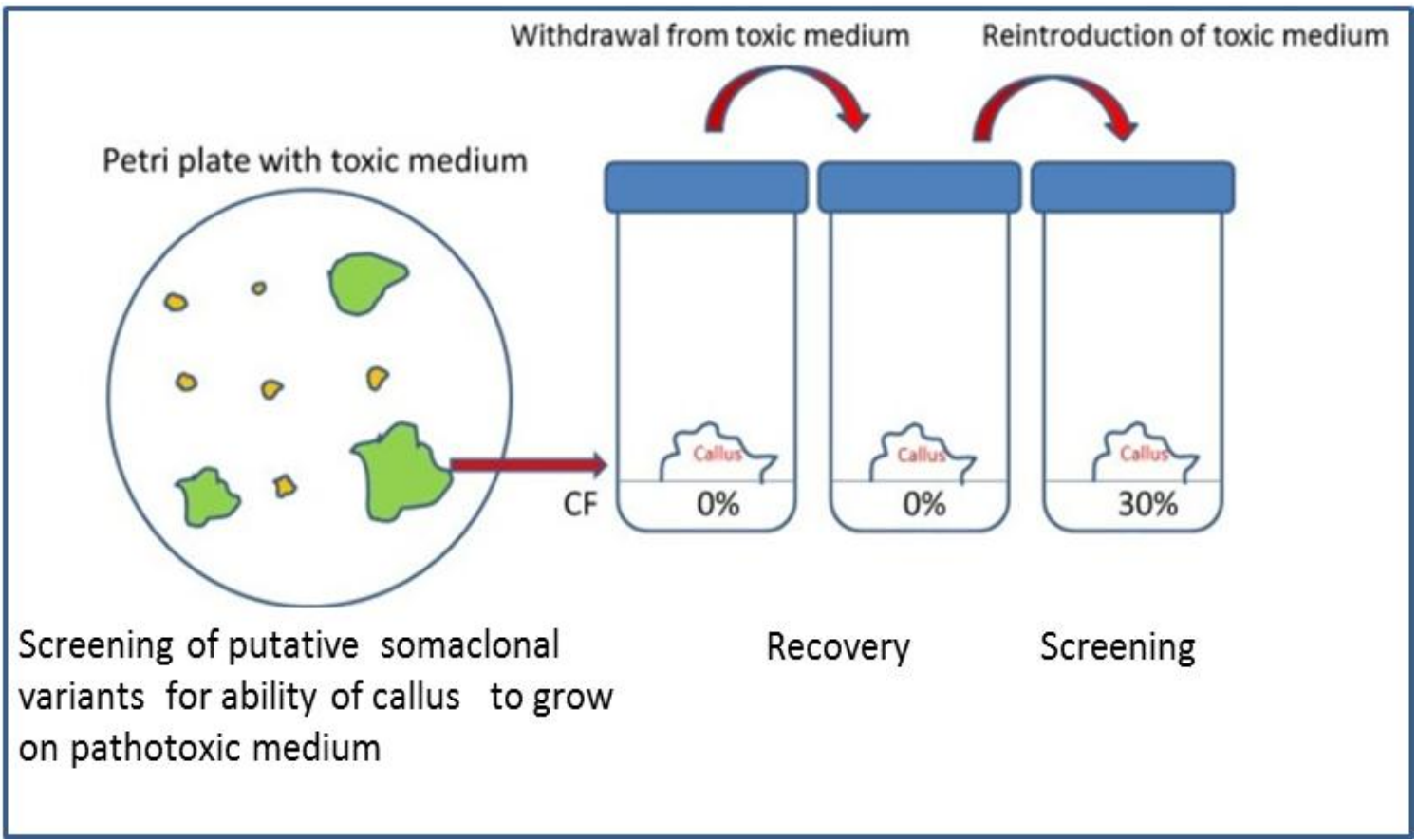

Fig 2. Schematic representation for a tissue culture methodology to evaluate stability of somaclonal variants

alterations, which are transmitted sexually to the progeny. Such SV based mutations can be very advantageous for improving a cultivar (11).

\section{Somaclonal variations in crop improvement}

Stable SVs have been generated in several plant species (12) and is a way to create variations and broaden the germplasm pool. In fact, somaclonal variation is a simple alternate technology aiding breeders for enhancing genetic variability relatively rapidly in crops that are difficult to breed or have low genetic variability $(11,13)$.

The SV breeding practice has led to several cultivars that have been successfully released with improved traits including plant architecture, disease resistance, yield, appearance, and abiotic stress tolerance. Some examples include Yidan No. 6 maize (Zea mays L.) with improved grain quality, CIMAP/bio-13 aromatic grass (Cymbopogon winterianus Jowitt) with enhanced oil yield, $\mathrm{He} \mathrm{Zu}$ No. 8 a wheat (Triticum aestivum L.) variant with high yield, rice variant DAMA with resistance to Picularia spp. 'Ono' somaclonal variant of sugarcane is resistant to eye-spot disease, Fiji disease and downy mildew, and generated from the susceptible cultivar 'Pindar' (14). A sweet potato somaclonal variant cultivar 'Scarlet' is comparable to the parent cultivar in yield and disease resistance, but shows a more desirable darker and more stable skin colour (15). Somaclonal variants of St. Augustine grass showed stable desirable variations during vegetative propagation (12). In vitro selection of desirable traits that have been commercially exploited in horticulture varieties through somaclonal variations are enumerated in a review by Krishna et al. in 2016 (11).
In India, somaclonal variation has been the biotechnological approach to produce commercial varieties. CIMAP (Central Institute for Medicinal and Aromatic Plants), Lucknow has released 'Bio 13' a somaclonal variant of Citronella java, a medicinal plant. This SV, Bio-13, has 37\% higher oil and $39 \%$ higher citronellol as compared to control varieties (16). A somaclonal variant of the $B$. juncea variety 'Varuna' has been released for commercial cultivation as 'Pusa Jai Kisan' (http://nrcpb.org/content/varieties-developed). The new variety has bolder seeds and yield advantage over the parent variety Varuna. Gupta et al. (2002) (17) developed a superior somaclonal variant of Rose-scented Geranium at CIMAP, India. Arun and coworkers (2003) (18) generated SVs $\left(R_{2}, R_{3}\right.$ and $R_{4}$ generations) from immature embryos of two spring wheat varieties, HUW-206 and HUW-234. These SVs displayed improved characters such as resistance to spot blotch disease and enhanced yield over the source varieties. A high sugared and high yielding SV of sugarcane (CoC 671), Co 94012, released as Phule Savitri in Maharastra (19), has better sucrose content and resistance to red rot and smut diseases.

\section{Selection pressure to induce disease resistance in vitro}

The conventional and more cumbersome method of obtaining SVs involves the field screening of resistance in a large population of plants, raised through in vitro callus cultures. A more targeted approach is the regeneration of disease resistant plants by generating resistant callus cultures selected on fungal toxin or culture filtrates (20-22). Somaclonal variation has applications in plant breeding and genetic improvement and generation of such novel variants can be enhanced by 
Table 2. Examples for molecular detection of Somaclonal variants in different crops

\begin{tabular}{|c|c|c|c|c|}
\hline Common name & Species & Source of variation & Detection method & Reference \\
\hline Tea & $\begin{array}{l}\text { Camellia sinensis (L.) } \\
\text { O. Kuntze }\end{array}$ & $\begin{array}{l}\text { Embryogenic culture, } \\
\text { genotype }\end{array}$ & $\begin{array}{l}\text { RFLP, RAPD, microsatellite } \\
\text { markers }\end{array}$ & $(62)$ \\
\hline Lemon & $\begin{array}{l}\text { Citrus limon (L.) } \\
\text { Burm }\end{array}$ & $\begin{array}{l}\text { Callus culture, gamma- } \\
\text { rays }\end{array}$ & Chromosome count, RAPD & (63) \\
\hline Coffee & Coffea arabica $\mathrm{L}$. & Embryogenic culture & AFLP & (64) \\
\hline Lemmon grass & $\begin{array}{l}\text { Cymbopogonflexuosus } \\
\text { (Nees ex Steud.) } \\
\text { Will.Watson }\end{array}$ & $\begin{array}{l}\text { Callus culture, } 2,4-\mathrm{D} \text {, } \\
\text { number of subcultures }\end{array}$ & RAPD & (65) \\
\hline Jamrosa & Cymbopogon hybrid & Callus culture, 2,4-D & Morphology, RAPD & $(42)$ \\
\hline Strawberry & Fragaria L. & 6-benzylaminopurine & Morphology, RAPD & (66) \\
\hline Soybean & Glycine $\max$ (L.) Merr. & $\begin{array}{l}\text { Embryogenic culture, 2,4- } \\
\text { D }\end{array}$ & RAPD & (67) \\
\hline Cotton & $\begin{array}{l}\text { Gossypium hirsutum } \\
\text { L. }\end{array}$ & $\begin{array}{l}\text { Callus culture, 2,4-D + } \\
\text { kinetin, duration in } \\
\text { culture }\end{array}$ & $\begin{array}{l}\text { Chromosome count, RAPD, } \\
\text { microsatellite markers }\end{array}$ & (68) \\
\hline Wild barley & $\begin{array}{l}\text { Hordeum } \\
\text { brevisubulatum } \\
\text { (Trin.) Link }\end{array}$ & Callus culture & $\begin{array}{l}\text { Sequence-specific amplification } \\
\text { polymorphism (S-SAP), AFLP, } \\
\text { MSAP }\end{array}$ & (69) \\
\hline Barley & Hordeum vulgare L. & Callus culture & $\begin{array}{l}\text { Inter-retrotransposon } \\
\text { amplified polymorphism } \\
\text { (IRAP), microsatellite markers }\end{array}$ & (70) \\
\hline Banana & Musa acuminata L. & $\begin{array}{l}\text { Genotype, explant source, } \\
\text { number of subcultures }\end{array}$ & RAPD & (71) \\
\hline Banana & Musa acuminata $\mathrm{L}$. & Explant & AFLP, MSAP & (72) \\
\hline Banana & Musa acuminata $\mathrm{L}$. & $\begin{array}{l}\text { Number of subcultures, } \\
\text { activation of transposable } \\
\text { element }\end{array}$ & $\begin{array}{l}\text { RAPD, inter-retrotransposon } \\
\text { amplified polymorphism } \\
\text { (IRAP), susceptibility to } \\
\text { fusarium wilt disease }\end{array}$ & (73) \\
\hline Banana & $\begin{array}{l}\text { Musa acuminata L.cv. } \\
\text { Rasthali }\end{array}$ & $\begin{array}{l}\text { Somatic embryo culture } \\
\text { screened for Fusarium } \\
\text { wilt resistance }\end{array}$ & cDNA-RAPD & (74) \\
\hline Rice & Oryza sativa L. & $\begin{array}{l}\text { Callus culture, genotype, } \\
\text { duration in culture }\end{array}$ & Morphology, RAPD & (75) \\
\hline Rice & Oryza sativa L. & $\begin{array}{l}\text { Callus culture, DNA } \\
\text { demethylation using 5- } \\
\text { azacytidine }\end{array}$ & RAPD, microsatellite markers & (76) \\
\hline Orchids & Phalaenopsis Hsiang Fei & Embryogenic culture & cDNA-AFLP & (77) \\
\hline Pea & Pisum sativum $\mathrm{L}$. & Callus culture, genotype & RAPD, microsatellite markers & (78) \\
\hline Sugarcane & Saccharum L. hybrid & Callus culture & $\begin{array}{l}\text { Morphology, chromosome } \\
\text { count, isozyme patterns }\end{array}$ & (79) \\
\hline Rye & Secale cereale L. & Embryogenic culture & Biochemical tests, AFLP & (80) \\
\hline Potato & Solanum L. & Genotype & Microsatellite markers & (81) \\
\hline Potato & Solanum tuberosum L. & $\begin{array}{l}\text { Callus culture, duration } \\
\text { of culture }\end{array}$ & Microsatellite markers & (82) \\
\hline Potato & Solanum tuberosum L. & Embryogenic culture & Chromosome count, AFLP & (83) \\
\hline Sorghum & Sorghum bicolor L. & Explant & Microsatellite markers & (84) \\
\hline Cocoa & Theobroma cacao L. & Embryogenic culture & $\begin{array}{l}\text { Cleaved amplified polymorphic } \\
\text { sequence (CAPS) }\end{array}$ & (85) \\
\hline
\end{tabular}


providing a suitable in vitro selection pressure (23). Exposure to phytopathotoxin, pathogen-wall material or secreted elicitors, has been a proven selection pressure to obtain disease resistant somatic variants of several crop plants $(11,24)$. In such a selection method, the cultures are selected by gradually increasing concentrations of culture filtrate or phytotoxin or by a constant challenge with either. Following such selection (Fig 1), the calli can be screened further on medium containing a higher concentration of the toxin or culture filtrate. The stability of the putative cultures can be tested by passing the cultures through several subcultures in recovery medium, devoid of the selection pressure. This is followed by screening of the recovered calli on phytopathotoxic medium (Fig. 2). The ability to survive and grow on such screening medium will give an indication of the stability of the adaptation observed in the putative SVs.

Somaclonal breeding programmes have been effective in developing disease-resistant crops $(25,26,22,27)$. Phytopathotoxins have been used as a proven selection pressure in callus cultures. The scientist Carlson in 1973 (21) was the first to report in vitro selection of callus for breeding purpose. Maize plants resistant to Helminthosporium maydis were generated by Gengenbach et al. (1977) (28), using culture filtrate selection pressure on callus cultures. Later, Behnke (1979) (29) regenerated Late Blight resistant potato plants from culture filtrateexposed callus $(22,29)$. Tomato (Lycopersicon esculentum) plants with improved resistance to Fusarium (Fusarium oxysporum) wilt were obtained by exposing calli to fusaric acid (30). Potato plants resistant to Early Blight (caused by Alternaria solani) and Late Blight (caused by Phytophthora infestans) were regenerated from protoplasts of potato ( $S$. tuberosum L.) varieties 'Rssset Burbank' (31) and 'Bintje' (32). This approach has also been used in rice to select for resistance against brown spot disease (33). Cerato and co-workers have shown that plants regenerated from potato cells selected in vitro with culture filtrate of Phytophthora infestans exhibited improvement in resistance as compared with the source plants (34).

In India, the selection pressure approach has been used in groundnut against Carcosporidium peronatum (35), and in chickpea cell lines against Fusarium oxysporum sp. cicero (36). Thakur et al. (2002) (37) carried out in vitro selection and regeneration of carnation (Dianthus cayophyllus L.) plants resistant to culture filtrate of Fusarium oxysporum f. sp. dianthi. Rao et al. (2006) (36) developed Pigeon Pea cell lines and regenerated plantlets from callus tolerant to culture filtrate of Fusarium odum Buttler. Saxena et al. (2008) (38) generated leaf blight-resistant Pelargonium graveolens (rose scented Geranium) plants by selection of callus with culture filtrate of Alternaria alternate. The resistance of sunflower
(Helianthus annuus L.) to Alternaria helinathi was improved by exposure of callus cultures to Alternaria culture filtrates (39). Bhardwaj et al. in 2012 (40) obtained resistant mutants of ginger (Zingiber officinale Rosc.) against wilt pathogen (Fusarium oxysporum f. sp. zingiberi Trujillo) by in vitro selection approach. More, recently, Krishna et al. (2016) (11) and Dehgahi and Joniyas, in 2016 (24) have reviewed the success of somaclonal variants and the use of pathogen toxin, wall elicitors and culture filtrate as a selection pressure to generate disease resistance in different crops.

\section{Molecular detection of somaclonal variants}

Efficient detection of alterations is essential to identify somaclonal variants that might possess useful agronomic traits. SVs have been detected and analyzed using different methods, including morphological, physiological, resistance evaluation, cytological, biochemical and molecular methods. At the molecular level, variations arise from changes in chromosome number or structure, or from subtle changes in the DNA itself (41).

Molecular analysis of variations at the DNA level is sensitive and will enable the detection of changes that are not obvious at the morphological level. Moreover, molecular techniques enable detection of variants in the callus or juvenile stages as opposed to morphological and physiological methods wherein regenerated or adult plant response are measured. Most importantly molecular detection methods will help identify genetically stable variations among a group of SVs that might have arisen due to either epigenetic changes or due to subtle but stable divergence at the DNA level. Molecular methods are useful tools to analyze the degree of divergence in SVs from the source calli or plant material.

Random Amplified Polymorphic DNA (RAPD) markers are the most commonly employed markers used to detect genetic variations in somaclonal variants $(42,43)$. In addition ISSR markers (44), AFLP, RFLP and microsatellite DNA markers have been used for molecular analysis of variations induced in tissue culture (Table 2) (45).

For effective detection and evaluation of somaclonal variants, it is preferable to use a multi thronged approach as shown in Table 2 . Somaclonal variants selected specifically for disease resistance are detected and evaluated using a combination of biochemical methods, tissue culture screening, disease resistance assays, cell viability tests and molecular marker methods. The selected putative SV calli are first screened on media containing toxic levels of the phytopathotoxin or CF and selected based on the response of the SV compared to the source calli (Fig 2). Further the calli cells may be analyzed by vital stains such as Trypan blue to evaluate the percentage viability in the calli in the screening 
plates or even after direct exposure to the pathogen. The calli can further be evaluated for the levels of defense enzyme activity such as superoxide dismutase, catalase, peroxidase as a response to exposure to the toxin or the pathogen. The shortlisted putative somaclonal variants showing significant resistance response to the pathogen or its elicitor, are further analyzed using molecular marker methods to ascertain that indeed the resistance adaptation observed is due to genetic changes.

\section{Drawbacks of the SV technology}

Selection of disease resistance in cell cultures is a rather simple process. However, the regeneration of plantlets from such somaclonal variant calli is usually difficult. The process of selection requires multiple subcultures of callus in medium containing the selection pressure and the phytohormone 2,4-D. Multiple subcultures resulting in prolonged exposure to auxins such as 2,4-D and the stress of the selection itself can result in the cells losing their regeneration potential. Another drawback of this method is the generation of pleotropic effects in regenerated plantlets. This can only be overcome by obtaining mulitiple somaclonal variants, so as to select a few amongst them having only the desirable traits. More focused and specific methods of tissue culture and selection that may overcome such road blocks need to be developed.

\section{Conclusion}

Several resistant somaclonal variant lines have been generated using the phytopathotoxin in vitro selection method. This approach is acceptable, simple and has high potential in obtaining desirable variability in crops. Moreover it has the potential of generating novel pathways of resistance that can be further exploited in crop improvement. An understanding of the underlying molecular pathways to resistance in somaclonal variants is lacking. These pathways need to be explored, and candidate genes identified for further exploitation in crop improvement. Only by understanding the many interactions that occur between host plants and pathogens can we utilize cell-culture approach of inducing variations to its fullest potential.

\section{Acknowledgements}

We acknowledge the financial support under the 'Innovative Young Biotechnologist Award' (IYBA) grant, Department of Biotechnology (DBT), Government of India to VSA.

\section{Authors' contribution}

VSA compiled and wrote the mini review. SB and SL compiled the Table 1 and the references section.

\section{References}

1. Vanderplank JE. Plant diseases: Epidemics and control. Academic Press, New York and London, 349pp.1963.

2. Oerke EC. Crop losses to pests. Agricultural Sci. 2006;144:31-43. https://doi.org/10.1017/S0021859605005708

3. Bandillo N, Raghavan C, Muyco PA, Sevilla MAL, LobinaI T, Ermita CJD, Tung CW, Mccouch S, Thomson M, Mauleon R, Singh RK, Gregorio G, Redoña E, Leung H. Multi-parent advanced generation inter-cross (magic) populations in rice: progress and potential for genetics research and breeding. $\quad$ Rice. 2013; 6: 11. https://doi.org/10.1186/1939-8433-6-11

4. Estrella H, Simpson J, Trujillo M. Transgenic plants: an historical perspective. Methods Mol Biol. 2005; 286: 3-32. https://doi.org/10.1385/1-59259-827-7:003

5. Jhansi RS, Usha R. Transgenic plants: types, benefits, public concerns and future. Pharmacy Research. https://doi.org/10.1016/j.jopr.2013.08.008

6. Larkin PJ, Scowcroft SC. Somaclonal variation- a novel source of variability from cell culture for plant improvement. Theor. Appl. Genet. 1981; 60: 197-214. https://doi.org/10.1007/BF02342540

7. Qin-Mei W, Li W. An evolutionary view of plant tissue culture: somaclonal variation and selection. Plant Cell Rep. 2012; 31: 1535-1547.

8. Meins F. Heritable variation in plant cell ann. Rev. Plant Physiol. 1983; 34:327-46.

9. Lee M, Phillips RL. The chromosomal basis of somaclonal variations. An Rev Plant Physiol Plant Mol Biol. 1988; 39: 413-37.

10. Phillips RL, Kaepppler SM, Peschke VM. Do we understand somaclonal variation?.Progress in plant cellular and molecular biology. Kluwer Acad. Publ, Dordrecht. 1990; 131-141.

11. Krishna H, Alizadeh M, Singh D, Singh U, Chauhan N, Eftekhari M, Sadh RK. Somaclonal variations and their applications in horticultural crops improvement. 3 Biotech. 2016; 6: 54. https://doi.org/ 10.1007/s13205-016-0389-7

12. Li R, Bruneau AH, Qu R. Tissue culture-induced morphological somaclonal variation in st.augustinegrass [Stenotaphrum secundatum (walt.) kuntze]. Plant Breed. 2010; 129: 96-99. https://doi.org/10.1111/j.1439-0523.2009.01647.

13. Rastogi J, Siddhant, Bubber P, Sharma BL. Somaclonal variation: a new dimension for sugarcane improvement. GERF Bulletin of Biosciences. 2015; 6: 5-10.

14. Egan BT. Chlorotic streak: diseases of sugarcane: major diseases edited by Ricaud C, Egan BT, Gillaspie AG, Hughes CG. Elsevier Science Publication. embryogenesis. Plant Breed. 1989; 121: 269-271.

15. Moyer JW, Collins WW. Scarlet sweet potato. Hort Sci. 1983; 18: 111-112.

16. Sarkar AN. Integrated horticulture development in eastern himalayas. M. D Publications. 1994.

17. Gupta R, Banerjee S, Mallavarapu GR, Sharma S, Khanuja SPS, Shasany AK, Kumar S. Development of a superior somaclone of rose-scented geranium 
and a protocol for inducing variants. Hort science. 2002; 37: 632-636.

18. Arun BA, Joshi K, Chand R, Singh BD. Wheat somaclonal variants showing earliness, improved spot blotch resistance and higher yield. Euphytica. 2003; 132: 235-241. https://doi:10.1023/A:1025097224408

19. Jalaja NC, Sreenivasan TV, Pawar SM, Bhoi PG, Garker RM. co 94012- a new sugarcane variety through somaclonal variation. Sugar Tech. 2006; 132-136. https://doi.org/10.1007/BF02943647

20. Heinz DJ. Sugarcane improvement through induced mutations using vegetative propagules and cell culture techniques. In: induced mutations in vegetatively propagated plants. ProcPannel Vienna, Sept 1972. IAEA pp. 53-59. https://doi.org/10.17660/ActaHortic.2007.735.19

21. Carlson PS. Methionine sulfoximine-resistant mutants of tobacco. Science. 1973; 180: 1366-1368. https://doi.org/10.1126/science.180.4093.1366

22. Behnke M. General resistance to late blight of Solanum tuberosum plants regenerated from callus resistant to culture filtrates of Phytophthora infestans. Theor. Appl. Genet. 1980; 56: 151-152. https://doi.org/10.1007/BF00286676

23. Lestari EG. In vitro selection and somaclonal variation for biotic and abiotic stress tolerance. Biodiversitas. 2006; 7: 297-301. https://doi.org/10.13057/biodiv/d070320

24. Dehgahi R, Subramaniam S, Zakaria L, Joniyas A. Review of research on in vitro selection of Dendrobium sonia-28, against Fusarium proliferatum. Int. J. Sci. Res. in Agricultural Sciences. 2016; $\quad 3: \quad 050-061$. http://dx.doi.org/10.12983/ijsras

25. Kintzios S, Koliopoulos A, Karyoti E, Drossopoulos J, Holevas CD, Grigoriu A, Panagopoulos. In vitro reaction of sunflower (Helianthus annus l.) to the toxin (s) produced by Alternaria alternata, the causal agent of brown leaf spot. Phytopathol. 1996; 144: $\quad 465-470 . \quad$ https://doi.org/10.1111/j.14390434.1996.tb00325

26. Thanutong P, Furusawa I, Yamamoto M. Resistant tobacco plants from protoplast derived calluses for their resistance to pseudomonas and alternaria toxins. Theor. Appl. Genet. 1983; 66: 209-215. https://doi.org/10.1007/BF00251145

27. Penna S, Vitthal SB, Yadav PV. In vitro mutagenesis and selection in plant cultures and their prospects for crop improvement. Bioremediation, Biodiversity and Bioavailability. 2012; 6: 6-14.

28. Gengenbach BG, Green CE, Donovan CM. Inheritance of selected pathotoxin resistance in maize plants regenerated from cell cultures. Proc Natl. Acad. Sci. 1977; 74: 5113-5117.

29. Behnke M. Selection of potato callus for resistance to culture filtrates of Phytophthora infestans and regeneration of resistant plants. Theor. Appl. Genet. 1979; 55: 69-71. https://doi.org/10.1007/BF00285192

30. Shahin EA, Spivey R. A single dominant gene for fusarium wilt resistance in protoplast-derived tomato plants. Theor. Appl. Genet. 1986; 73: 164169. https://doi.org/10.1007/BF00289270
31. Shepard JF, Bidney D, Shahin E. Potato protoplasts in crop improvement. Science. 1980; 208: 17-24. https://doi.org/10.1126/science.208.4439.17

32. Burg HCJ, Ramulu KS, Bredemeijer GMM, Roest S, Dhijkuis P, Hoogen JJV, Houwing A. Patterns of phenotypic and tuber protein variation in plants derived from protoplast of potato (Solanum tuberosum l. cv bintje). Plant Sci. 1989; 64: 113-124. https://doi.org/10.1016/0168-9452(89)90157

33. Ling DH, Vidhyasekharan P, Borromeo ES, Zapata FJ, Mew TW. In vitro screening of rice germplasm for resistance to brown spot disease using Phytotoxin. Theor. Appl. Genet. 1985; 71: 133-135. https://doi.org/10.1007/BF00278266

34. Cerato C, Manici LM, Borgatti S, Alicchio R, Ghedini R, Ghinelli A. Resistance to late blight [Phytophthora infestans (mont.) de bary] of potato plants regenerated from in vitro selected calli. Potato Research. 1993; 36: 341-351. https://doi.org/10.1007/BF02361801

35. Venkatachalam P, Rao KS, Kishore PBK,Jayabalan N. Regeneration of late leaf spot resistant groundnut plants from Carcosporidium personatum culture filtrate treated callus. Curr. Sci. 1998; 74 :

61-65. http://www.jstor.org/stable/24100665

36. Rao S, Basavaraj K, Kaviraj CP. In vitro selection of pigeon pea cell lines and regeneration of plantlets from tolerant callus to culture filtrate of Fusarium odum Buttler. Plant Cell Biotech. Mol Bio. 2006; 7(1\&2): 69-72.

37. Thakur M, Sharma D, Sharma S. In vitro selection and regeneration of carnation (Dianthus cayophyllus l.) plants resistant to culture filtrate of Fusarium oxysporum f. sp. dianthi. Plant Cell Rep. 2002; 20: 825-828. https://doi.org/10.1007/s00299001-0412-1

38. Saxena G, Verma PC, Rahman L, Banerjee S, Shukla RS, Kumar S. Selection of leaf blight-resistant Pelargonium graveolens plants regenerated from callus resistant to a culture filtrate of Alternaria alternate. Crop Protection. 2008; 27: 558-565. https://doi.org/10.1016/j.cropro.2007.08.013

39. Rao S, Ramgopal S. Effect of Alternaria helianthi culture filtrate on callus and regeneration of plantlets from tolerant callus in sunflower (Helianthus annuus 1.). Indian Journal of Biotechnology. $\quad$ 2010;9: $187: \quad 191$. http://nopr.niscair.res.in/handle/123456789/7798

40. Bhardwaj SV, Thakur T, Sharma R, Sharma P. In vitro selection of resistant mutants of ginger (Zingiber officinalerosc.) against wilt pathogen (Fusarium oxysporum f. sp. Zingiber itrujillo). Plant Dis Res. 2012; 27: 194-199.

41. Gostimsky SA, Kokaeva ZG, Konovalov FA. Studying plant genome variation using molecular markers. Russ J Genet. 2005; 41:3 78-88. https://doi.org/10.1007/s11177-005-0101-1

42. Nayak S, Debata BK, Srivastava VK, Sangwan NS. Evaluation of agronomically useful somaclonal variants in jamrosa (a hybrid cymbopogon) and detection of genetic changes through RAPD. Plant Sci. 2003; 164: 1029-1035. https://doi.org/10.1016/S0168-9452(03)00090-6

43. Kumar N, Modi AR, Singh AS, Gajera BB, Patel AR, Patel MP, Subhash N. Assessment of genetic fidelity 
of micropropagated date palm Phoenix dactylifera L.) plants by RAPD and ISSR markers assay. Physiol. Mol Biol. 2010; 6: 207-213. https://doi.org/10.1007/s12298-010-0023-9

44. Saravanan S, Sarvesan R, Vinod MS. Identification of DNA elements in somaclonal variants of Rauvolfia serpentine (L.) arising from indirect organogenesis as evaluated by ISSR analysis. Indian J. of Sci. and Tech. 2011; 4: 1241-1245.

45. Bairu MW, Aremu AO, Staden JV. Somaclonal variation in plants: causes and detection methods. Plant Growth Regul. 2011; 63: 147-173. https://doi.org/10.1007/s10725-010-9554-x

46. Sharma NK, Skidmore DI. In vitro expression of partial resistance to Phytophthora palmivora by shoot cultures of papaya. Plant Cell Tiss. Org. 1988; 14: 187-196. https://doi.org/10.1007/BF00043409

47. Song HS, Lim SM, Widholm JM. Selection and regeneration of soybeans resistant to the pathotoxic culture filtrates of Septoria glycines. Phytopathol. 1977; 84: 948-951.

48. Ganesan $M$, Jayabalan N. Isolation of disease tolerant cotton (Gossypium hirsutuml. cv. svpr 2) plants by screening somatic embryos with fungal culture filtrate. Plant Cell Tiss. Org. 2006; 87: 273284. http://www.jstor.org/stable/41998136

49. Chawla HS, Wenzel G. In vitro selection of barley and wheat for resistance against Helminthosporium sativum. Theor. Appl. Genet. 1987; 74: 841-845. https://doi.org/10.1007/BF00247566

50. Fujime F, Fujime G. Use of culture filtrates of Pyrenochaeta lycopersici in tests for selecting tolerant varieties of tomato. J. Plant Pathol. 2003; 85: 131-133. http://www.jstor.org/stable/41998136

51. Hartman CL, Mccoy TJ, Knous TR. Selection of alfalfa (Medicago sativa) cell lines and regeneration of plants resistant to the toxin(s) produced by Fusarium oxysporum f. sp. medicaginis. Plant Sci.Lett. $\quad 1984 ; \quad 34: \quad 183-219$. https://doi.org/10.1016/0304-4211(84)90141

52. McCoy TJ. Tissue culture selection for disease resistant plants. Iowa State J. Res. 1988; 62: 503-521.

53. Vidysekaran P, Ling DH, Borromeo ES, Zapata FJ, Mew TW. Selection of brown spot- resistant rice plant from Helminthosporium oryzae toxinresistant cultures. Annals of Applied Biol. 1990; 117: 515-523. $\quad$ https://doi.org/10.1111/j.17447348.1990.tb04818

54. Vos JE, Berjak MHS, Watt MP, Toerien AJ. In vitro selection and commercial release of guava wilt resistant rootstocks. Acta. Horticulturae. 1998; 513: 69-79.

https://doi.org/10.17660/ActaHortic.1998.513.7

55. Bajpai A, Chandra R, Mishra M, Tiwari RK. Regenerating Psidium spp. for screening wilt resistance rootstock under in vitro conditions. Acta Horticulturae. 2007; 735: 145-154.

56. Maier FJ, Oettler G. Selection for the fusarium toxin deoxynivalenol in callus culture of triticale. In Third European Fusarium Seminar, IHARR, Poland. 1992; 43-49.

57. Mohanraj D, Padmanaban P, Karunakaran M. Effect of pytotoxin of Colletrichum falcatum went. (Physalophora tucumanensis) on sugarcane in tissue culture. Acta. phytopathologicaet. entomologica Hungarica 2003;38:21-28.

58. Behnke M. Selection of dihaploid potato callus for resistance to culture filtrate of Fusarium oxysporum. Pflanzenzuchtg. 1980; 85: 254-258.

59. Jayasankar S, Litz RE. Characterization of embryogenic mango cultures selected for resistance to Colletotrichum gloeosporioides culture filtrate and phytotoxin. Theor. Appl. Genet. 1998; 96: 823-831. https://doi.org/10.1007/s001220050808

60. Deng ZN, Gentile A, Domina F, Nicolosi E, Tribulato E. Selecting lemon protoplasts for insensitivity to Phoma tracheiphila toxin and regenerating tolerant plants. J. Am. Soc.Hortic Sci. 1995; 120: 902-905.

61. Zhang LQ, Cheng ZH, Khan MA, Zhou YL. In vitro selection of resistant mutant garlic lines by using crude pathogen culture filtrate of Sclerotium cepivorum australas. Plant Pathol. 2012; 41: 211217. https://doi.org/10.1007/s13313-011-0109-z

62. Devarumath RM, Nandy S, Rani V, Marimuthu S, Muraleedharan N, Raina SN. RAPD, ISSR and RFLP fingerprints as useful markers to evaluate genetic intergrity of diploid and triploid elite tea clones representing Camellia sinensis (China type) and $C$. assamica ssp. assamica (Assam type). Plant Cell Rep. 2002; 21: 166-173.

63. Orbovic V, Syvertsen JP, Bright D, Clief VDL, Graham JH. Growth of citrus seedlings and their susceptibility to Phytophthora root rot are affected by PO3 and PO4 sources of phosphorus. Plant Nutr. 2008; 31: 774-787.

64. Sanchez TLF, Quiroz FF, Loyola VV, Infante D. Culture-induced variation in plants of Coffea arabica cv. Caturrarojo, regenerated by direct and indirect somatic embryogenesis. Mol Biotechnol. 2003; 23: 107-115.

65. Bhattacharya S, Dey T, Bandopadhyay T, Ghosh P. Genetic polymorphism analysis of somatic embryoderived plantlets of cymbopogon flexuosus through RAPD assay. Plant Biotechnol Rep. 2008; 2: 245-252.

66. Biswas MK, Dutt M, Roy UK, Islam R, Hossain M. Development and evaluation of in vitro somaclonal variation in strawberry for improved horticultural traits. Sci. Hort. 2009; 122: 409-416.

67. Gesteira AS, Otoni WC, Barros EG, Moreira MA. RAPD - based detection of genomic instability in soybean plants derived from somatic. Plant Breed. 2002; 121: 269-271. https://doi.org/10.1046/j.14390523.2002.00708.x

68. Jin S, Mushke R, Zhu H, Tu L, Lin Z, Zhang Y, Zhang $\mathrm{X}$. Detection of somaclonal variation of cotton (Gossypium hirsutum) using cytogenetics, flow cytometry and molecular markers. Plant Cell Rep. 2008; 27: 1303-1316.

69. Li X, Yu X, Wang N, Feng Q, Dong Z, Liu L, Shen J, Liu B. Genetic and Epigenetic instabilities induced by tissue culture in wild barely (Hordeum brevisubulatum (Trin) Link). Plant Cell, Tissue and Organ culture. 2007; 90: 153-168.

70. Campbell B, LeMare S, Piperidis G, Godwin I. IRAP, a retrotransposon-based marker system for the detection of somaclonal variation in barley. Mol Breed. 2010; 27: 103-206. https://doi.org/10.1007/s11032-010-9422-4

71. Sheidai M, Aminpoor H, Noormohammadi Z, Farahani F. Genetic variation induced by tissue culture in 
Banana (Musa acuminate L.) cultivar Cavandish Dwarf Masoud. Geneconserve. 2009; 9: 1-10.

72. James AC, Pereza ES, Herrera VA, Martinez O. Application of the amplified fragment length polymorphism (AFLP) and the methylationsensitive amplification polymorphism (MSAP) techniques for the detection of DNA polymorphism and changes in DNA methylation in micropropagated bananas. In: Jain SM, Swennen R (eds) Banana improvement: cellular, molecular biology, and induced mutations. Science Publishers. 2004; 287-306.

73. Asif MJ, Othman RY. Characterization of Fusarium wilt-resistant and fusarium wilt-susceptible somaclones of banana cultivar rastali (Musa AAB) by random amplified polymorphic DNA and retrotransposon markers. Plant Mol Biol. Rep. 2005; 23: 241-249.

74. Ghag SB, Shekhawat UKS, Ganapathi TR. Characterization of fusarium wilt resistant somaclonal variants of banana $\mathrm{cv}$. rasthali by cDNA-RAPD. MolBiol Rep. 2014; 41(12): 7929-7935. https://doi.org/10.1007/s11033-014-3687-3

75. Sultana R, Tahira F, Tayyab H, Khurram B, Shiekh R. RAPD characterization of somaclonal variation in indica basmati rice. Pak J Bot. 2005; 37: 249-262.

76. Ngezahayo F, Dong Y, Liu B. Somaclonal variation at the nucleotide sequence level in rice (Oryza sativa L.) as revealed by RAPD and ISSR markers, and by pairwise sequence analysis.Theor.Appl Genet. 2007; 48: 329-336.

77. Hsu TW, CTsai WC, Wang DP, Lin S, Hsiao YY, Chen WH, Chen HH. Differential gene expression analysis by cDNAAFLP between flower buds of Phalaenopsis Hsiang Fei cv. H. F. and its somaclonal variant. Plant Sci. 2008; 175: 415-422.

78. Kuznetsova OI, Ash OA, Hartina GA, Gostimskij SA. RAPD and ISSR analyses of regenerated pea Pisum sativum L. plants. Russ J. Genet. 2005; 41: 60-65.
79. Heinz DJ, Mee GWP. Morphologic, cytogenetic and enzymatic variation in Saccharum species hybrid clones derived from callus tissue. Amer J. Bot. 1971; 58: $257-262$

80. De la PR, Gonza'lez A, Ruiz M, Polanco C. Somaclonal variation in rye (Secalecereale L.) analyzed using polymorphic and sequenced AFLP markers. In vitro Cell DevBiol Plant. 2008; 44: 419426.

81. Aversano R, Savarese S, Nova JMD, Frusciante L, Punzo M, Carputo D. Genetic stability at nuclear and plastid DNA level in regenerated plants of Solanum species and hybrids. Euphytica. 2009; 165: 353-361. https://doi.org/10.1007/s10681-0089797-Z

82. Albani MC, Wilkinson MJ. Inter simple sequence repeat polymerase chain reaction for the detection of somaclonal variation. Plant Breed. 1998; 117: 573-575.

83. Sharma S, Bryan G, Winfield M, Millam S. Stability of potato (Solanum tuberosum L.) plants regenerated via somatic embryos, axillary bud proliferated shoots, microtubers and true potato seeds: a comparative phenotypic, cytogenetic and molecular assessment. Planta. 2007; 226: 14491458 .

84. Zhang M, Wang H, Dong Z, Qi B, Xu K, Liu B. Tissue culture induced variation at simple sequence repeats in sorghum (Sorghum bicolor L.) is genotype-dependent and associated with downregulated expression of a mismatch repair gene, MLH3. Plant Cell Rep. 2010; 29: 51-59.

85. Rodrı'guez LC, Bravo H, Wetten A, Wilkinson M. Detection of somaclonal variation during cocoa somatic embryogenesis characterised using cleaved amplified polymorphic sequence and the new freeware Artbio. Mol Breeding. 2010; 25: 501516. 